\title{
Continuous glucose monitoring systems in well-controlled children with type 1 diabetes mellitus
}

\author{
Zastosowanie systemu ciągłego monitorowania glikemii u dzieci z dobrze kontrolowaną cukrzycą \\ typu 1
}

\author{
${ }^{1}$ Emilia M. Kowalczyk, ${ }^{2}$ Marta Adamczyk, ${ }^{2}$ Justyna Pietrzyk, ${ }^{2}$ Barbara Jastrzębska, \\ ${ }^{3}$ Agnieszka Szypowska
}

\author{
${ }^{1}$ Department of Pediatric Diabetology and Pediatrics, Pediatric Teaching Clinical Hospital of the Medical \\ University of Warsaw, Poland \\ ${ }^{2}$ Medical University of Warsaw, Students' Scientific Association, Poland \\ ${ }^{3}$ Department of Pediatrics, Medical University of Warsaw, Poland
}

\begin{abstract}
Introduction: Numerous studies have demonstrated the clinical benefits of using continuous glucose monitoring (CGM) systems among patients with type 1 diabetes (T1D).

Aim of the study was to assess the effectiveness of CGM on metabolic control in children with T1D and well-controlled disease prior to the study.

Material and methods: This prospective analysis included 99 children (46 girls) at the median age of 11.23 years and diabetes duration of at least 1 year (median: 5.16 years), generally well controlled metabolically (median $\mathrm{HbA}_{1 c}:$ 7.0\%), and treated with continuous subcutaneous insulin infusion (CSII). The patients had used CGM for at least 150 days. We analysed the participants in subgroups based on baseline $\mathrm{HbA}_{1 \mathrm{c}}<7 \%, \geq 7 \%$, age, and sex.

Results: Children with baseline $\mathrm{HbA}_{1 \mathrm{c}}<7 \%$ were characterized by significantly increased $\mathrm{HbA}_{1 \mathrm{c}}$ after the median of 273 days $(217$; $320)$ of CGM usage $(6.3 \%$ vs. $6.6 \%$, respectively; $p=0.002)$. No significant change in $\mathrm{HbA}_{1 c}$ was noted in children with baseline $\mathrm{HbA}_{1 \mathrm{c}} \geq 7 \%$ (7.5\% vs. $7.4 \%$, respectively; $\left.p=0.191\right)$, but $20 \%$ of the group reached the target of HbA $<7.0 \%$. The analysis of CGM data revealed that no group achieved the CGM targets of good metabolic control. Total daily insulin requirements remained stable in both groups $(p=0.752 ; p=0.274)$, but the amount of basal insulin increased statistically in both groups $(p=0.009 ; p \leq 0.001)$. Conclusions: The application of CGM provides detailed information concerning glycaemic control and is beneficial in some, but not all, T1D children with good diabetes control.
\end{abstract}

Key words:

sensor, $\mathrm{HbA}_{1 \mathrm{c}^{\prime}}$ glycaemic control, CGM, continuous glucose monitoring system.

\section{Streszczenie}

Wstęp: W wielu dotychczas przeprowadzonych badaniach wykazano liczne korzyści wynikające z zastosowania systemu ciągłego monitorowania glikemii (CGM) u dzieci chorujących na cukrzycę typu 1 (CT1).

Cel pracy: Celem przeprowadzonego badania było oszacowanie wpływu zastosowania CGM na kontrolę metaboliczną CT1 u dzieci i młodzieży z dotychczas dobrze kontrolowaną chorobą.

Materiał i metody: Przeprowadzono prospektywną analizę danych 99 pacjentów (46 dziewczynek) z medianą wieku 11.23 roku chorujących na CT1 co najmniej 1 rok (mediana 5.16 roku), z cukrzycą dobrze wyrównaną metabolicznie (mediana HbA 1 < $7 \%$ ) leczonych ciągłym podskórnym wlewem insuliny za pomocą pompy. Pacjenci używali CGM przez co najmniej 150 dni. Podzielono i przeanalizowano dane uczestników zależnie od wyjściowego stężenia $\mathrm{HbA}_{1 \mathrm{c}}<7 \%$, $\geq 7 \%$, wieku oraz płci.

Wyniki: Pacjenci początkowo dobrze wyrównani metabolicznie uzyskali istotny statystycznie wzrost $\mathrm{HbA}_{1 \mathrm{c}}$ po 273 dniach obserwacji (odpowiednio 6.3\% vs. 6.6\%; $p=0.002$ ). Nie odnotowano istotnych statystycznie różnic dotyczących HbA wśród pacjentów z wyjściowym $\mathrm{HbA}_{1 \mathrm{c}} \geq 7 \%$ (odpowiednio $7.5 \%$ vs. $7.4 \% ; p=0.191$ ), ale $20 \%$ grupy osiągnęło poziom HbA $<7.0 \%$. Analiza danych z CGM wykazała, iż żadna z grup nie osiągnęła celów leczenia. Całkowite dobowe zapotrzebowanie na insulinę nie uległo zmianie w obu grupach $(p=0.752 ; p=0.274)$, ale doszło do zwiększenia ilości insuliny podawanej jako baza $(p=0.009 ; p \leq 0.001)$. 
Wnioski: Zastosowanie CGM dostarcza szczegółowych informacji na temat kontroli glikemii i jest korzystne u wielu, lecz nie wszystkich dzieci leczonych ciągłym podskórnym wlewem insuliny za pomocą pompy, które osiągnęły dobrą kontrolę metaboliczną choroby. Słowa kluczowe:

sensor, $\mathrm{HbA}_{1 c^{\prime}}$ kontrola glikemii, CGM, ciągły monitoring glikemii.

\section{Introduction}

The T1D Exchange Clinic Registry collected data from over 22 thousand participants between the years 2016 and 2018. Unexpectedly, they found that only $17 \%$ of children achieved the goal of treatment according to the American Diabetes Association (ADA), i.e. $\mathrm{HbA}_{1 \mathrm{c}}$ below 7.5\% [1]. Between the years 2012 and 2018 CGM was the fastest growing technology, with a sudden growth in the number of users from 7 to 30 percent of diabetic patients. Similarly, CGM use among children under the age of 6 years surged at that time from just $4 \%$ to $51 \%$ [1]. This observation unveiled the need for more efficient means to improve glycaemic control. Currently, dynamic development of diabetes supporting technologies is observed. The increasing use of continuous glucose monitoring (CGM) provides safe and effective diabetes control.

Numerous studies have demonstrated the clinical benefits of using CGM, especially as regards the efficacy in lowering $\mathrm{HbA}_{1 \mathrm{c}}$ across all age groups without increasing the incidence of hypoglycaemia or even reducing the duration of hypoglycaemia [2-9]. The reduction in $\mathrm{HbA}_{1 \mathrm{c}}$ ranged from $0.22 \%$ up to $2.05 \%[6,8-13]$. The combination with a system of continuous subcutaneous insulin infusion (CSII), which is a sensoraugmented pump therapy, provided additional benefits, as demonstrated in numerous studies $[3,6]$. Adherence to the use of CGM is a crucial parameter for efficacy with an additional $0.15 \%$ decrease in $\mathrm{HbA}_{1 \mathrm{c}}$ for every day of sensor usage per week $[6,7,9,12]$. Surprisingly, only $38 \%$ of the paediatric population used a CGM sensor over $75 \%$ of the time: $30 \%$ of patients aged $15-24$ and $50 \%$ of those aged 8 to 14 years $[10,14]$. The early initiation of CGM within 1 year from type 1 diabetes mellitus (T1D) diagnosis was also associated with better glucose control and a reduced rate of emergency department visits due to hypo- and hyperglycaemia [15]. The potential ability to reduce the risk of hypoglycaemia is a huge advantage of CGM, especially in the paediatric population, because most children experienced asymptomatic postprandial and nocturnal hypoglycaemic events. The parents of children using CGM reported decreased stress and anxiety about their child's health and improved quality of life $[2,3,16]$. These devices may also contribute to the reduction of diabetes care costs by alerting patients to potential glucose deviations and avoiding hospitalizations due to severe hypoglycaemia and diabetes ketoacidosis episodes $[2,3,5,7]$.

The 2018 ISPAD guidelines recommended CGM for all children. They clearly state that "each child should have access to technology and materials for self-monitoring of glucose measurements to adequately test in order to optimize diabetes care" [17]. Nowadays, sensor-augmented insulin pump thera- py is the most beneficial and recommended way of treating patients with T1D [17]. There is a paucity of data to demonstrate whether children who primarily achieved the treatment target based on the $\mathrm{HbA}_{1 \mathrm{c}}$ level could gain any additional benefit from using CGM.

\section{Aim of the study}

The aim of the study was to assess the effectiveness of CGM on metabolic control in children with T1D and well-controlled disease prior to the study.

\section{Material and methods}

The study was conducted in accordance with the ethical standards and with the Helsinki Declaration of 1964, as revised in 2013. The Bioethics Committee of the Medical University of Warsaw approved the study, and the participants provided their written informed consent.

For the purposes of the study, 165 patients were initially enrolled. They were all patients of the Department of Paediatric Diabetology and Paediatrics, Paediatric Teaching Clinical Hospital of the Medical University of Warsaw and Outpatient Department, who were using RT-CGM (real time-continuous glucose monitoring) diabetes treatment between March and December 2018. All patients were children of Caucasian origin, with a T1D duration over 1 year, treated with CSII, not on RT-CGM at baseline, who were initiated and used RT-CGM for at least 150 days. There were no restrictions regarding age or $\mathrm{HbA}_{1 \mathrm{c}}$ levels. Thirty-five children were excluded because of a follow-up period shorter than 150 days, and 31 because of irregular CGM use (below 6 days per week) or discontinuation of CGM for various reasons (e.g. an irritation in the sensor area, discomfort caused by too many electronical devices, too many adhesive plasters on the skin, differences in outcomes between CGM and a glucose meter). A total of 99 participants (46 girls), were finally included in the analysis. Data were prospectively collected up to March 2019. The participants used different types of insulin: lispro, aspart, and glulisine. Participants were divided into 2 main groups: those with well-controlled diabetes at baseline, who maintained $\mathrm{HbA}_{1 \mathrm{c}}$ below 7\%, and those inadequately-controlled with $\mathrm{HbA}_{1 \mathrm{c}}$ equal or above $7 \%$. Comparisons between $\mathrm{HbA}_{1 \mathrm{c}}$ groups, but also between age groups (up to 8 years, 9-12 years, 13-17 years) and gender groups (girls, boys) were performed. The patients used different RT-CGM systems: the Enlite ${ }^{\mathrm{TM}}$ sensor with the MiniLink ${ }^{\mathrm{TM}}$ Transmitter and MiniMed ${ }^{\circledR}$ Paradigm VEO ${ }^{\text {m }}$ insulin pump (Medtronic MiniMed, Northridge, California) or the Enlite ${ }^{\mathrm{TM}}$ sensor with the MiniMed $\AA$ Guardian ${ }^{\text {TM }}$ Connect Transmitter and MiniMed $\AA$ 
Paradigm VEO ${ }^{\mathrm{TM}}$ insulin pump (Medtronic MiniMed, Northridge, California) or Accu-Chek ${ }^{\circledR}$ Combo insulin pump (Roche). Prior to applying CGM, the participants were obliged to take part in a 1-day training session led by an experienced Medtronic company assistant to obtain a detailed explanation of how to use the system properly. It was required that patients wear a sensor for at least 6 days per week. All patients had access to constant medical assistance.

\section{Outcomes}

The primary outcome of our study was the comparison of $\mathrm{HbA}_{1 \mathrm{c}}$ level between the date of the connection to CGM and the date of the last control visit in the Outpatient Clinic. Mean 24-h glucose values with SD (standard deviation), the coefficient of variation for glucose (CV), time-in-range (TIR), time above range (TAR), time below range (TBR), hypoglycaemic events, total daily dose of insulin (TDD), basal dose of insulin, and body mass index zscore (BMl z-score), which was calculated using the World Health Organization (WHO) child growth standards (www.who.int), were also compared. Data from insulin pumps and Contour ${ }^{\circledR}$ Plus Link Meter glucose meters were transmitted to CareLink ${ }^{\circledR}$ Pro software and turned into CareLink $\AA$ Pro reports. The calculations of the mean 24-h glucose concentrations and SD were established based on data from the glucose meter at baseline and CGM at the end of follow-up. To assess the glycaemic variability CV was calculated with the following computation: ([SD of glucose]/[mean glucose])*100\%. Data concerning \% TIR, TAR, and TBR were available from the CGM system. Target glucose levels were established between $70-180 \mathrm{mg} / \mathrm{dl}$ (3.9-10.0 mmol/l), below target $<70 \mathrm{mg} / \mathrm{dl}(<3.9 \mathrm{mmol} / \mathrm{l})$, and above target $>180 \mathrm{mg} / \mathrm{dl}$ (>10.0 mmol/l). Outcomes concerning CGM and their analysis were performed according to the recommendations by Battelino et al. [18]. $\mathrm{HbA}_{1 \mathrm{c}}$ was measured with high-performance liquid chromatography with a nondiabetic range of $4.1-6.4 \%(21-46 \mathrm{mmol} / \mathrm{mol})$ with the D-10 Hemoglobin Testing System, Bio-Rad Laboratories, USA.

\section{Statistical analysis}

All analyses were performed using GraphPad Prism, Version 8.4.2. Nominal variables are presented as n (\% of group), continuous variables as median (Q1; Q3) due to the lack of normal distribution. Data normality was verified based on the Shapiro-Wilk test. Group comparisons for nominal variables were conducted with the Fisher exact test or $\chi^{2}$ test, as appropriate. The Wilcoxon signed rank test was used for the paired comparisons of clustered data. Continuous variables were compared with the Kruskal-Wallis and Mann-Whitney $U$ test. All tests were 2-tailed, with the differences being considered significant at the level of $p$ value $\leq 0.05$

\section{Results}

A total of 99 participants met the study inclusion criteria and used CGM for the median time of 273 days $(217 ; 320)$. The study group was generally well controlled metabolically with the median $\mathrm{HbA}_{1 \mathrm{c}}$ of $7.0 \%(6.3 ; 7.5)$. The patients were at the me- dian age of 11.23 years $(8.85 ; 14.36)$, and the median diabetes duration was 5.16 years $(2.87 ; 8.67)$.

Patients with good metabolic control, $\mathrm{HbA}_{1 \mathrm{c}}<7 \%$ (46 participants), showed no gender predominance, were younger (11.23 years vs. 9.60 years, $p=0.007$, respectively), and had shorter T1D duration (5.16 years vs. 4.40 years, $p=0.010$, respectively) in comparison with the inadequately controlled group. The $24 \mathrm{~h}$ average glucose concentration (AVG) in the inadequately controlled group $\left(\mathrm{HbA}_{1 \mathrm{c}} \geq 7 \%\right)$ was statistically higher $(171 \mathrm{mg} / \mathrm{dl}$ vs. $142 \mathrm{mg} / \mathrm{dl}, p=0.002)$ with similar glycaemic variability (similar SD and CV). Both groups had similar daily insulin requirements (total and basal daily dose). All of them had a BMI z-score in the normal range. Table I presents the baseline characteristics of the study group.

No episodes of acute metabolic decompensation, diabetic ketoacidosis, or severe hypoglycaemic events were noted during the follow-up. At the end of follow-up significantly higher $\mathrm{HbA}_{1 \mathrm{c}}$ levels were observed (6.30\% vs. $\left.6.60 \% ; p=0.002\right)$ in children who had a better metabolic control at baseline. The median increase of $\mathrm{HbA}_{1 \mathrm{c}}$ amounted to $0.20 \%$, and, interestingly, the proportion of participants who maintained the baseline $\mathrm{HbA}_{1 \mathrm{c}}$ level below $7 \%$ decreased by $20 \%$. Nevertheless, the group still achieved good metabolic control at the end, and approximately half of the group (48\%) reduced the $\mathrm{HbA}_{1 \mathrm{c}}$ level by $\geq 0.3 \%$. The analysis of the second group (inadequately controlled) demonstrated that the value of $\mathrm{HbA}_{1 \mathrm{c}}$ did not change during the study $(p=0.191)$, but a decrease in $\mathrm{HbA}_{1 \mathrm{c}}$ level $\geq 0.3 \%$ was noted in around $70 \%$ of the participants. It is also worth emphasizing that the number of patients who reached the target of $\mathrm{HbA}_{1 \mathrm{c}}$ below $7.0 \%$ increased remarkably, and they represented $20 \%$ of the group at the end of follow-up. Interestingly, CV was statistically higher after applying RT-CGM in participants with $\mathrm{HbA}_{1 \mathrm{c}}<7 \%$ (40.94\% vs. $32.22 \%, p=0.028$ ) with stable SD and mean 24-h glucose concentration ( $p=0.523$, $p=0.296$, respectively). Stable CV $(p=0.579)$, SD $(p=0.150)$, and mean 24 -h glucose concentration $(\rho=0.576)$ were noted in the inadequately controlled participants.

An intergroup comparison after RT-CGM introduction (Table II) revealed a sustained tendency towards poorer metabolic control in the inadequately controlled group at baseline. They achieved higher $\mathrm{HbA}_{1 \mathrm{c}}$ values $(7.40 \%$ vs. $6.60 \%, p \leq 0.0001)$ with a higher mean glucose concentration $(166 \mathrm{mg} / \mathrm{dl}$ vs. $150 \mathrm{mg} / \mathrm{dl}$, $p=0.0002)$ in comparison with the well-controlled participants. Glycaemic variability (SD and CV) was similar in both groups. Increased TAR values were noted in the group with baseline $\mathrm{HbA}_{1 \mathrm{c}} \geq 7 \%$ (38.00\% vs. $\left.26.50 \%, p=0.021\right)$ with similar TBR in both groups $(8.50 \%$ vs. $6 \%, p=0.307)$. Total daily insulin requirements remained stable in both groups $(<7 \% p=0.752$; $\geq 7 \% p=0.274$ ), but the basal/bolus proportion changed during the study. The amount of basal insulin increased statistically in both groups $(<7 \% p=0.009 ; \geq 7 \% p \leq 0.001)$.

During the study the participants did not change their weight based on BMI Z-score in both groups: well controlled metabolically $(p=0.475)$ and inadequately controlled $(p=0.858)$. Children maintained their weight within the normal range during the whole observation period 
Table I. Baseline characteristics of study participants with the main outcomes

\begin{tabular}{|c|c|c|c|}
\hline & \multicolumn{3}{|l|}{ Study population } \\
\hline & Baseline & After RT-CGMS & $p$ \\
\hline Participants, $n$ & 99 & 99 & \\
\hline Median age, years & $11.23(8.85 ; 14.36)$ & & \\
\hline Gender, F/M & $46 / 53$ & & \\
\hline Diabetes duration, years & $5.16(2.87 ; 8.67)$ & & \\
\hline $\mathrm{HbA}_{1 \mathrm{c}}, \%$ & $7.0(6.30 ; 7.50)$ & $7.0(6.60 ; 7.50)$ & ns \\
\hline $\mathrm{HbA}_{1 \mathrm{c}}, \mathrm{mmol} / \mathrm{mol}$ & $53(45.00 ; 58.00)$ & $53(49.00 ; 58.00)$ & ns \\
\hline $\mathrm{HbA}_{1 \mathrm{c}}$ change from baseline, $\%$ & & $0.05(-0.30 ; 0.40)$ & ns \\
\hline $\mathrm{HbA}_{1 \mathrm{c}}<7.00 \%, \mathrm{n}(\%)$ & $46(46)$ & $47(47)$ & ns \\
\hline 24-h mean glucose concentration, mg/dl & $157(138 ; 172)$ & $153(138 ; 166)$ & ns \\
\hline $\mathrm{SD}, \mathrm{mg} / \mathrm{dl}$ & $70(57 ; 88)$ & $61(53 ; 74)$ & ns \\
\hline $\mathrm{CV}, \%$ & $49.18(37.10 ; 53.46)$ & $41.33(35.80 ; 46.56)$ & ns \\
\hline TDD, U/kg & $0.8(0.66 ; 0.93)$ & $0.8(0.69 ; 0.94)$ & ns \\
\hline Basal Rate, U/kg & $0.27(0.21 ; 0.35)$ & $0.3(0.25 ; 0.36)$ & $<0.001$ \\
\hline BMI Z-score & $0.41(-0.10 ; 0.91)$ & $0.42(-0.24 ; 0.88)$ & ns \\
\hline
\end{tabular}

Continuous parameters are presented as median and lower and upper quartile (Q1;Q3). P-values are indicated when significant $(p<0.05)$ Basal Rate - dose of basal insulin; BMI - body mass index; CV - coefficient of variation; F - female; $\mathrm{HbA}_{1 \mathrm{c}}$ - glycated haemoglobin; $\mathrm{M}$ - male; $\mathrm{n}$ - number of subjects; ns - non-significant; SD - standard deviation; TDD - total daily dose of insulin

\section{Results of the entire cohort}

No significant changes were observed in median $\mathrm{HbA}_{1 \mathrm{c}}$ in the entire cohort after RT-CGM usage compared to baseline (7.0\% vs. $7.0 \%, p=0.279)$, but over one-third of patients $(34 \%)$ achieved $\mathrm{HbA}_{1 \mathrm{c}}$ reduction of at least $0.3 \%$. Around $52 \%$ of all the participants had good glycaemic control $\left(\mathrm{HbA}_{1 \mathrm{c}}<7 \%\right)$ at baseline, and the proportion was stable throughout the study (51 participants vs. 51 participants, respectively). Lower glycaemic variability was observed at the end of follow-up. The CV ratio (49.18\% vs. $41.33 \%, p=0.022)$ was significantly lower with similar SD (70 mg/dl vs. $61 \mathrm{mg} / \mathrm{dl}, p=0.451)$ and mean glucose values $(p=0.282)$. The total daily dose of insulin remained stable, but the distribution changed. Significantly more basal insulin was delivered $(p \leq 0.0001)$. General outcomes are presented in Table I.

The highest baseline $\mathrm{HbA}_{1 \mathrm{c}}$ value was noted among adolescents (13-17 years): $7.3 \%$ (56 mmol/mol) in comparison with $6.60 \%(49 \mathrm{mmol} / \mathrm{mol})$ in the youngest children and $6.90 \%$ (52 $\mathrm{mmol} / \mathrm{mol}$ ) in the age range $9-12$ years, $p=0.021$. As regards age analysis, no differences concerning $\mathrm{HbA}_{1 \mathrm{c}}$, glycae- mic variability, and mean glucose concentration were found between participants at the beginning of the study and at the end of follow-up. Figure 1 presents $\mathrm{HbA}_{1 \mathrm{c}}$ changes during the study. About half of the participants of the youngest group (44\%) achieved $\mathrm{HbA}_{1 \mathrm{c}}$ improvement of over $0.3 \%$, but the differences were not statistically significant between groups with $p=0.400$ (33\% participants aged $9-12$ years and $28 \%$ aged 13-18 years). Baseline insulin requirements were the lowest in the youngest children $-0.68 \mu / \mathrm{kg}(0.55 ; 0.81)$ - in comparison with $0.80 \mu / \mathrm{kg}(0.67 ; 0.91)$ in the participants aged between 9 and 12 years and $0.89 \mu / \mathrm{kg}(0.75 ; 1.08)$ in adolescents, $p=0.001$. After RT-CGM implementation a significant increase in daily insulin requirements was noted among participants aged 9-12 years: $0.86 \mu / \mathrm{kg}(0.71 ; 0.96 ; p=0.040)$. Increased basal insulin requirements were also noted in the youngest group $(0.20 \mu / \mathrm{kg}$ vs. $0.25 \mu / \mathrm{kg} ; p=0.021)$ and in those aged 9-12 years $(0.25 \mu / \mathrm{kg}$ vs. $0.29 \mu / \mathrm{kg}, p=0.021)$. The tendency towards higher baseline $\mathrm{HbA}_{1 \mathrm{c}}$ values was observed more commonly among boys in comparison with girls, i.e. $7.2 \%$ $(6.4 ; 7.8)$ vs. $6.8 \%(6.3 ; 7.3)$, but without statistical importance $(p=0.093)$. The analysis of sex groups revealed no significant 


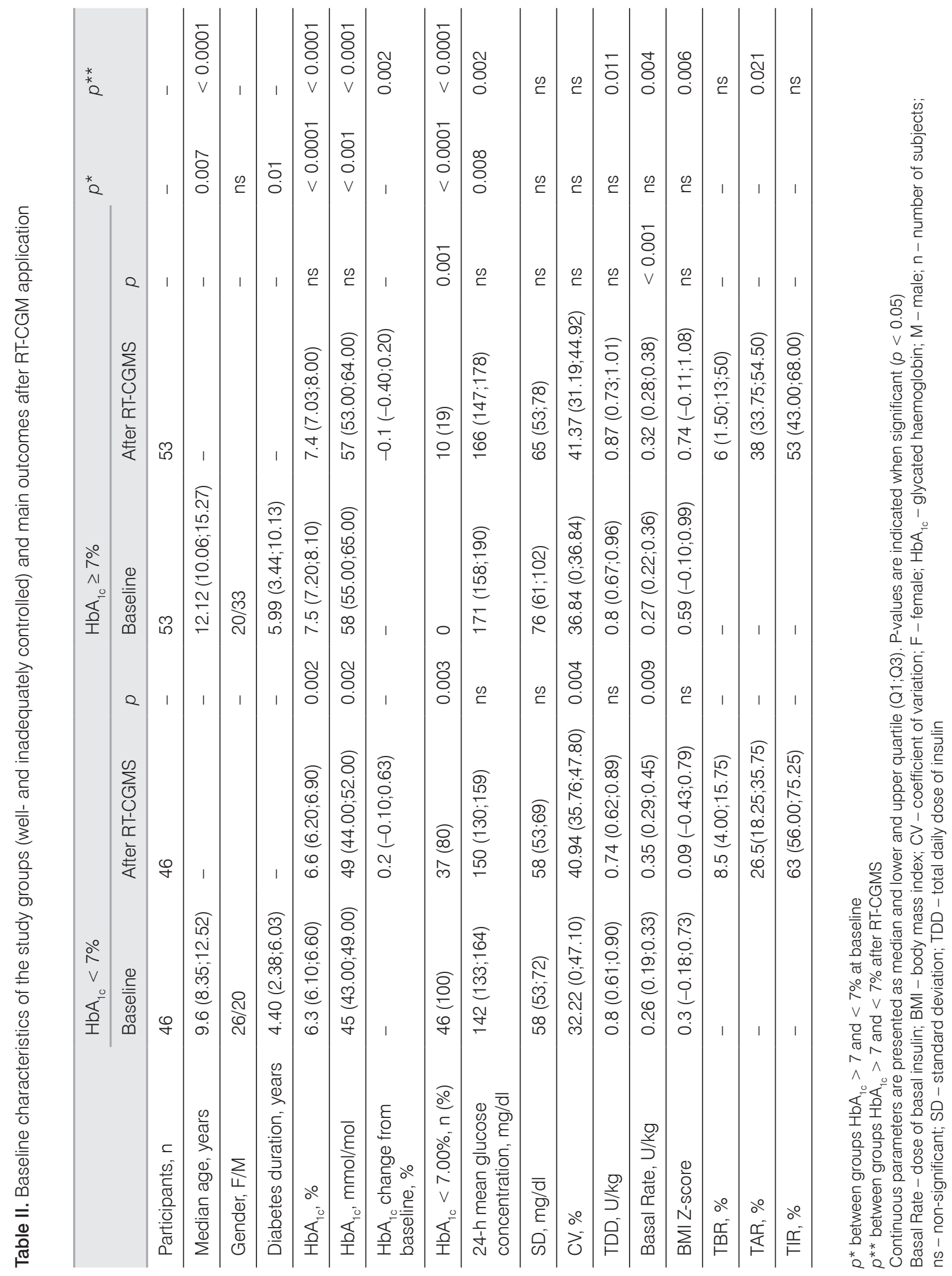




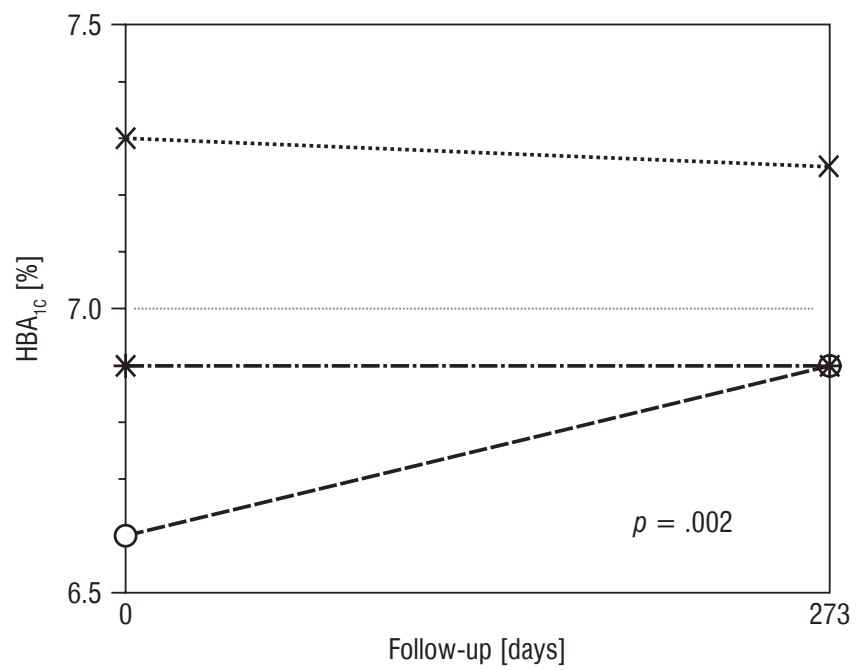

-O- $\leq 8$ years $\quad$-*... 9-12 years $\quad \cdots . \times \cdots$ 13-17 years

Figure 1. $\mathrm{HbA}_{1 \mathrm{c}}$ comparison between age groups before and after CGM implementation

differences in the outcomes concerning glycaemic control $\left(\mathrm{HbA}_{1 \mathrm{c}}\right.$, mean glucose concentration, CV, SD). After RT-CGM implementation TAR values of $30 \%$ vs. $35 \%(p=0.949)$, TBR $6 \%$ vs. $8.5 \%(p=0.875)$, and TIR $58 \%$ vs. $57 \%(p=0.799)$ were similar among girls and boys, respectively. No baseline differences concerning BMl z-score were noted in relation to gender and age. The BMI Z-score was stable throughout the study period in all age groups and among both girls and boys.

\section{Discussion}

In our study we investigated the metabolic consequences after applying RT-CGM in children treated with CSII. We compared 2 main groups: patients with well-controlled T1D at baseline with $\mathrm{HbA}_{1 \mathrm{c}}$ below $7 \%$ and those with inadequately controlled disease $\left(\mathrm{HbA}_{1 \mathrm{c}} \geq 7 \%\right)$. The $\mathrm{HbA}_{1 \mathrm{c}}$ threshold of good metabolic control was established according to the 2018 ISPAD guidelines [17].

The results showed that the usage of an RT-CGM system in routine daily practice did not cause any further decrease in $\mathrm{HbA}_{1 \mathrm{c}}$ in children who had good metabolic control at baseline, and it did not lead to lower glycaemic variability. After RT-CGM application the increased level of $\mathrm{HbA}_{1 \mathrm{c}}$ and $\mathrm{CV}$ was observed with the same SD and mean glycaemic concentration. The CV increase in the well-controlled group needs to be treated with caution. The comparison was performed based on data from glucose meters at baseline and data from RT-CGM at the end of the follow-up. The lack of knowledge concerning the values of blood glucose testing by glucose meter per day before the study is a limitation of the study. Data from RT-CGM did not differ significantly between groups at the end of the follow-up, except for a significant difference concerning TAR. Interestingly, neither group met the good metabolic control criteria based on CGM data according to Battelino et al.: CV $<36 \%$, TBR $<4 \%$, $\mathrm{TAR}<25 \%$, and TIR $>70 \%$ [18]. Nevertheless, some patients in both groups reduced their $\mathrm{HbA}_{1 \mathrm{c}}$ levels. Within the group of inadequately controlled children, $20 \%$ were able to reach the target of $\mathrm{HbA}_{1 \mathrm{c}}$ below $7.0 \%$ afterwards, and $80 \%$ of wellcontrolled group still maintained adequate metabolic control. The increase in $\mathrm{HbA}_{1 \mathrm{c}}$ value after RT-CGM usage with the simultaneous maintenance of good metabolic control might be due to a decreased number of hypoglycaemic events, which was shown in other studies but not in ours. Battelino et al. showed also the impact of CGM on hypoglycaemia in wellcontrolled children and adults with baseline $\mathrm{HbA}_{1 \mathrm{c}}$ below $7.5 \%$ [19]. In their study, 120 participants were recruited and 58 used CGM for 26 weeks. Participants using the monitoring system reduced time in hypoglycaemia ( $<63 \mathrm{mg} / \mathrm{dl}$ ) from the mean of 49 min to 29 min per day with a concomitant decrease in $\mathrm{HbA}_{1 \mathrm{c}}$ (difference: $-0.27 \%$; $95 \% \mathrm{Cl}$ : from -0.47 to $-0.07 ; p=0.008$ ) $[7,19]$. Some patients, the users of the Enlite ${ }^{\mathrm{TM}}$ sensors with the MiniMed ${ }^{\circledR}$ Paradigm VEO ${ }^{\mathrm{TM}}$ insulin pump, probably used the low glucose suspend (LGS) feature, which may partly account for the increase in $\mathrm{HbA}_{1 \mathrm{c}}$. Another explanation might be the fact that children in the group with $\mathrm{HbA}_{1 \mathrm{c}}<7 \%$ were young, with a median age of 9 years. In consequence, some of them might not have acquired the skill of self-interpretation of the trend arrows and proper reaction to alarms, especially when they were away from home or at school. It is also possible that in some participants the glycaemic limits were set at a higher level than recommended because of the fear of hypoglycaemic events. The participants making up the group with inadequate diabetes control were mostly adolescents. It is a well-known and common clinical problem that adolescents are the group of patients with the highest glycaemic variability and the poorest metabolic control. The T1D Exchange Registry showed that people aged 13-26 years had the poorest glycaemic control compared to other age groups. Those who used all the technological advances (CSII and CGM) achieved the mean $\mathrm{HbA}_{1 \mathrm{c}}$ value of $8.3 \%$ compared to $8 \%$ in those using insulin injections and CGM or $9 \%$ on CSII therapy [1]. Our study also showed that adolescents (aged 13-17 years) had the highest baseline $\mathrm{HbA}_{1 \mathrm{c}}$ value (median 7.3\%). Indeed, based only on age analysis (regardless of baseline $\mathrm{HbA}_{1 \mathrm{c}}$ level), some of them accomplished an improvement in $\mathrm{HbA}_{1 \mathrm{c}}$, and, undoubtedly, they could benefit from the technology of RT-CGM because it might encourage and stimulate their independence. The youngest group included children below 8 years. They achieved the lowest $\mathrm{HbA}_{1 \mathrm{c}}$ level, most probably because of huge parental involvement in diabetes care.

The potential benefits of CGM among patients with wellcontrolled T1D have been examined in only a few studies. The Juvenile Diabetes Research Foundation (JDRF) conducted a randomized study involving 129 participants, both adults and children, treated with insulin pump therapy or multiple daily injections with $\mathrm{HbA}_{1 \mathrm{c}}$ below 7\% [20]. Of those, 67 patients started using CGM and the rest were assigned to the control group, using only self-monitoring of blood glucose (SMBG). 
At the end of the follow-up (26 weeks) the researchers found differences favouring the CGM group concerning lower $\mathrm{HbA}_{1 \mathrm{c}}$, $\mathrm{HbA}_{1 \mathrm{c}}$ improvement of over $0.3 \%$ (31\% vs. $5 \%$ ), and shorter duration of hypoglycaemia per day (from $91 \mathrm{~min}$ to $54 \mathrm{~min}$ ) [20]. $\mathrm{HbA}_{1 \mathrm{c}}$ lowering was not associated with the incidence of severe hypoglycaemic events [20]. Our findings are not in line with their results, but the study design and the study group were different. We included a more homogeneous population (children treated with CSII), and all the participants used the RT-CGM system. Our results also vary from a previous study that was also conducted by JDRF researchers. They enrolled 83 adults with T1D, who used CGM to evaluate the long-term effects. Thirty-four of the participants had $\mathrm{HbA}_{1 \mathrm{c}}$ below $7 \%$ and were observed for 1 year [21]. Those patients maintained stable $\mathrm{HbA}_{1 \mathrm{c}}$ at $6.4 \%$ with a low rate of severe hypoglycaemic events [21]. The study population did not include children, which might have contributed to the noted differences.

Data concerning insulin requirements after applying CGM are inconsistent. Eleftheriadou et al. conducted a prospective multicentre trial in suboptimally-controlled adult patients (median age 32 years) with baseline $\mathrm{HbA}_{1 c}>7 \%$. They demonstrated that the average total daily dosage, daily basal insulin dosage, and daily bolus insulin dosage increased significantly after the use of CGM [22]. Conversely, the study carried out on a metabolically well controlled group with $\mathrm{HbA}_{1 \mathrm{c}}<7 \%$ revealed that TDD among children (8-14 years old) using CGM and controls using SMBG was equal (mean $0.8 \pm 0.1 \mu / \mathrm{kg}$ vs. $0.8 \pm 0.3 \mu / \mathrm{kg}$ ) [20]. The JDRF group also noted no differences in daily insulin requirements associated with CGM use [21]. We reached analogous results in well-controlled patients and those with inadequate control. Daily insulin requirements were stable in our participants during the observation period, but we found the necessity of increasing the amount of basal insulin. Thanks to the CGM system the participants were able to notice more episodes of hyperglycaemia, especially during the night, which translated into a higher basal dose of insulin. Another possible explanation is the fact that trend arrows could prompt partici-

\section{References}

1. Foster NC, Beck RW, Miller KM, et al. State of Type 1 Diabetes Management and Outcomes from the T1D Exchange in 2016-2018. Diabetes Technol Ther 2019; 21: 66-72. doi: 10.1089/dia.2018. 0384.

2. Condren M, Sabet S, Chalmers LJ, et al. Technology for Augmenting Type 1 Diabetes Mellitus. J Pediatr Pharmacol Ther 2019; 24 : 99-106. doi: 10.5863/1551-6776-24.2.99.

3. Olczuk D, Priefer R. A History of Continuous Glucose Monitors (CGMs) in Self-Monitoring of Diabetes Mellitus. Diabetes \& Metabolic Syndrome: Clinical Research \& Reviews 2018; 12: 181-187. doi: 10.1016/j.dsx.2017.09.005

4. Rodbard D. Continuous Glucose Monitoring: A Review of Recent Studies Demonstrating Improved Glycemic Outcomes. Diabetes Technol Ther 2017; 19: 25-37. doi: 10.1089/dia.2017.0035. pants to temporarily increase the basal dose as a right reaction Data from the aforementioned studies were consistent with our finding that the application of CGM did not lead to weight gain and $\mathrm{BMI}$ increase $[21,22]$.

\section{Strengths and limitations of the study}

The strength of this study is a unique population of wellcontrolled, motivated children with T1D treated with CSII and RT-CGM. Approximately half of them had an $\mathrm{HbA}_{1 \mathrm{c}}<7 \%$ $(<53 \mathrm{mmol} / \mathrm{mol})$ during at baseline. Moreover, the group with inadequate metabolic control also included children with quite good glycaemic control, with the median $\mathrm{HbA}_{1 \mathrm{c}}$ of $7.5 \%$. Such a group of patients facilitated the real-life analysis of how CGM influenced $\mathrm{HbA}_{1 \mathrm{c}}$.

The limitation of the study is the lack of information concerning glycaemic variability, TAR, TBR, and TIR from blinded CGM prior to the application of RT-CGM and the lack of knowledge on the values of blood glucose testing by glucose meter per day prior to the study.

\section{Conclusions}

Adequate glycaemic control is still a challenge among patients with T1D. The effect of RT-CGMs on $\mathrm{HbA}_{1 \mathrm{c}}$ and CGM-derived measures of glycaemic control remains to be elucidated, especially in well-controlled children. In our study, the participants, who were classified as well-controlled at baseline did not even achieve the CGM targets of good metabolic control after the intervention. Adequate glycaemic control is still a challenge among patients with T1D. The intervention appeared more beneficial for the participants from the inadequately controlled group, who achieved similar results to those with good metabolic control. Thanks to new technologies, such as RT-CGM systems, some, but not all, children with well-controlled diabetes may achieve excellent metabolic control and reduce or maintain $\mathrm{HbA}_{1 \mathrm{c}}$ in the target range $(<7 \%)$.

5. Rodbard D. Continuous Glucose Monitoring: A Review of Successes, Challenges, and Opportunities. Diabetes Technol Ther 2016; 18 3-13. doi: 10.1089/dia.2015.0417.

6. Joubert M, Reznik Y. Personal continuous glucose monitoring (CGM) in diabetes management: Review of the literature and implementation for practical use. Diabetes Res Clin Pract 2012; 96: 294-305. doi: 10.1016/j.diabres.2011.12.010.

7. Vazeou A. Continuous blood glucose monitoring in diabetes treatment. Diabetes Res Clin Pract 2011; 93: 125-130. doi: 10.1016/ S0168-8227(11)70028-6

8. Chetty VT, Almulla A, Odueyungbo A, et al. The effect of continuous subcutaneous glucose monitoring (CGMS) versus intermittent whole blood finger-stick glucose monitoring (SBGM) on hemoglobin A1c (HBA1c) levels in Type I diabetic patients: a systematic review. Diabetes Res Clin Pract 2008; 81: 79-87. doi: 10.1016/j. diabres.2008.02.014 
9. Langendam M, Luijf YM, Hooft L, et al. Continuous glucose monitoring systems for type 1 diabetes mellitus (Review). Cochrane Database of Systematic Reviews 2012; 1: 1-116. doi: 10.1002/14651858. CD008101.pub2.

10. Bergenstal RM, Tamborlane WV, Ahmann A, et al. Sensor-Augmented Pump Therapy for A1C Reduction (STAR 3) Study: Results from the 6-month continuation phase. Diabetes Care 2011; 34: 2403-2405. doi: 10.2337/dc11-1248.

11. Rachmiel M, Landau Z, Boaz M, et al. The use of continuous glucose monitoring systems in a pediatric population with type 1 diabetes mellitus in real-life settings: the AWeSoMe Study Group experience. Acta Diabetologica 2014; 52: 323-329. doi: 10.1007/ s00592-014-0643-6.

12. The Juvenile Diabetes Research Foundation Continuous Glucose Monitoring Study Group. Factors Predictive of Use and of Benefit From Continuous Glucose Monitoring in Type 1 Diabetes. Diabetes Care 2009; 32: 1947-1953. doi: 10.2337/dc09-0889.

13. Block CD, Manuel-y-Keenoy B, Van Gaal L. A Review of Current Evidence with Continuous Glucose Monitoring in Patients with Diabetes. Journal of Diabetes Science and Technology. 2008; 2: 718-727. doi: 10.1177/193229680800200426

14. The Juvenile Diabetes Research Foundation Continuous Glucose Monitoring Study Group. Continuous Glucose Monitoring and Intensive Treatment of Type 1 Diabetes. N Engl J Med 2008; 359: 1464-1476. doi: 10.1056/NEJMoa0805017.

15. Mulinacci G, Alonso GT, Snell-Bergeon JK, et al. Glycemic Outcomes with Early Initiation of Continuous Glucose Monitoring System in Recently Diagnosed Patients with Type 1 Diabetes. Diabetes Technol Ther 2019; 21: 6-10. doi: 10.1089/dia.2018.0257.

16. Burckhardt MA, Fried L, Bebbington K, et al. Research: Educational and Psychological Aspects Use of remote monitoring with continuous glucose monitoring in young children with Type 1 diabetes: the parents' perspective. Diabet Med 2019; 36: 1453-1459. doi: 10.1111/dme.14061.

17. DiMeglio LA, Acerini CL, Codner E, et al. ISPAD Clinical Practice Consensus Guidelines 2018: Glycemic control targets and glucose monitoring for children, adolescents, and young adults with diabetes. Pediatr Diabetes 2018; 19: 105-114. doi: 10.1111/ pedi.12737.

18. Battelino T, Danne T, Bergenstal RM, et al. Clinical Targets for Continuous Glucose Monitoring Data Interpretation: Recommendations From the International Consensus on Time in Range. Diabetes Care 2019; 42: 1593-1603. doi: 10.2337/dci19-0028.

19. Battelino T, Phillip M, Bratina N, et al. Effect of continuous glucose monitoring on hypoglycemia in type 1 diabetes. Diabetes Care 2011; 34: 795-800. doi: 10.2337/dc10-1989.

20. Juvenile Diabetes Research Foundation Continuous Glucose Monitoring Study Group. The Effect of Continuous Glucose Monitoring in Well-Controlled Type 1 Diabetes. Diabetes Care 2009; 32: 1378-1383. doi: 10.2337/dc09-0108.

21. Juvenile Diabetes Research Foundation Continuous Glucose Monitoring Study Group. Sustained Benefit of Continuous Glucose Monitoring on A1C, Glucose Profiles, and Hypoglycemia in Adults With Type 1 Diabetes. Diabetes Care 2009; 32: 2047-2049. doi: 10.2337/ dc09-0846.

22. Eleftheriadou I, Didangelos T, Pappas AC, et al. Improvement of metabolic control after 3-month use of real-time continuous glucose monitoring in patients with type 1 diabetes: a multicenter study in Greece. Hormones (Athens) 2019; 18: 443-450. doi: 10.1007/ s42000-019-00153-1. 